\title{
"WHAT DOES THE UNIVERSITY HAVE TO DO WITH IT?": PERCEPTIONS OF RAPE CULTURE ON CAMPUS AND THE ROLE OF UNIVERSITY AUTHORITIES
}

\author{
Z. Orth* \\ Public Health PhD candidate \\ e-mail: zaidaorth@gmail.com / https://orcid.org/0000-0002-2895-0417

\section{B. van Wyk*} \\ School of Public Health \\ e-mail: bvanwyk@uwc.ac.za / https://orcid.org/0000-0003-1032-1847
}

\section{Andipatin*}

Department Psychology

mandipatin@uwc.ac.za / https://orcid.org/0000-0003-1805-9361

*University of the Western Cape

Bellville, South Africa

\section{ABSTRACT}

In April 2016, the \#Endrapeculture protests spread across South African university campuses. These protests raised awareness of university policies regarding rape and sexual assault cases on campus. The protesters accused the university management of perpetuating a rape culture through policies which reinforced victim-blaming and protected perpetrators of sexual assault. Through the use of hashtag campaigns and public demonstrations, the movement quickly gained momentum across social and mainstream media. This momentum served to put pressure on university administrations to be accountable for cases of sexual assault on campuses. Movements calling out universities for perpetuating a rape culture are not unique to South Africa; as similar movements have been initiated at other university campuses across the globe. This article examines the rape culture discourse that emerged on Facebook following the \#Endrapeculture protests. Specifically, we look at how people perceived rape culture and the role of university management in handling sexual assault. Naturalistic observation was used on comments from public posts and articles from Facebook relating to the 2016 \#Endrapeculture protest. These comments were subjected to qualitative content analysis. Two main themes are discussed in this article: Rape/Rape Culture and The Role of Universities and Law Enforcement. Many commenters indicated that cases of rape and sexual assault should be addressed by law enforcement and should not be handled by university management. We argue that rape culture education should be formalised in South Africa.

Keywords: Social media, qualitative content analysis, naturalistic observation, rape culture 


\section{INTRODUCTION}

Sexual assault on university and college campuses have been identified as a public health concern (Dematteo et al. 2015, 227; Fedina, Holmes and Backes 2018, 77). Various health consequences of sexual assault have been documented, including mental health conditions such as depression, post-traumatic stress disorder, anxiety and eating disorders; physical injury; sexually transmitted infections; and chronic illnesses (Fedina, Holmes and Backes 2018, 77). Despite various attempts to address the problem of sexual assault on campus through research and intervention, the incidence of sexual assault on campuses remains high (Phipps et al. 2018, 2; Morales 2015, 22).

In the past few decades, feminist scholars and activists have argued that the high rates of sexual assault on campuses are associated with the institutional culture of the university, which is described as reinforcing a rape culture (Rentschler 2014, 66; Giraldi and Monk-Turner $2017,116)$. First conceptualised in 1975, rape culture refers to a culture in which male sexual violence is normalised and victims are consequently blamed for their own assault (Brownmiller 1975, 11; Zaleski et al. 2016, 922). Recently, discussions around rape culture have proliferated both in public and academic discourses (Gouws 2018, 4; Gqola 2015, 2; Rentschler 2015, 353). This can be attributed to the rise in social media social movements and digital feminist activism aimed at raising awareness about issues such as rape culture (Rentschler 2015, 353).

Student activists have utilised social media to simultaneously raise awareness about sexual assault on campuses and to hold university authorities accountable for the role they play in perpetuating the problem (Linder et al. 2016, 231). For example, the roll out of the 2014 White House Task Force to Protect Students from Sexual Assault project developed by the then president of the United States of America (US), Barack Obama, was put in motion after students from US universities used social media to draw attention to rape culture on campuses across the US (Linder et al. 2016, 233). The campaign started in 2013 when students from a southeastern US university challenged the way the administration dealt with their sexual assault cases by filing a complaint with the Office of Civil Rights (OCR). Simultaneously, student activists used social media to create awareness of the problem. As a result, other students from other US universities started speaking out and proceeded to file their own complaints with the OCR. Since then, students from over 150 US campuses have filed complaints with the OCR, thereby prioritising sexual assault in the US government.

In April 2016, South African (SA) universities received a similar backlash as student activists initiated the \#Endrapeculture protests. These protests were a representation of students' frustration with the way university management dealt with sexual assault cases; which 
students perceived as reinforcing victim-blaming and supporting perpetrators of sexual assault (Gouws 2018, 3). The initial protest was launched at a SA university under the campaign \#Chapter212 - in reference to the SA constitution chapter regarding the safety and dignity of the student body (Gouws 2018, 3; Wazar 2016). The campaign consisted of sticking posters related to rape culture all over campus. While these posters were removed by the campus security, images of the campaign had already spread across social media. Following this, other SA universities followed suit by launching their own \#chapter212, \#Endrapeculture and \#nakedprotest campaigns. Through the use of the hashtags, the protest movement quickly gathered momentum on social media, thereby allowing members of the public to share relevant information, show their support or engage with others in debate online.

The aim of this article is to present findings from a study which explored rape culture discourses that emerged in the Facebook comment section of articles and posts relating to the South African \#Endrapeculture protests. Specifically, we look at the public perceptions of rape culture on SA university campuses, and the perceived role of the university administrations. Additionally, we discuss the role that social media played in holding the university management accountable to students and the public.

\section{RAPE CULTURE IN SOUTH AFRICA}

The recent discourse of rape culture in mainstream platforms can be attributed to the growth of digital feminism and activism. However, a cultural theory of rape first originated in the 1970s during the rise of second wave feminism. Term "rape culture" was first coined in 1975 by Brownmiller in her book, Against our will (Brownmiller 1975, 1; Johnson and Johnson 2017, 2; Rentschler 2014, 66). Brownmiller's book is considered a turning point in academic history as it was one of the first books that described rape as a political and social problem, rather than an individual crime of passion. Indeed, in the first chapter Brownmiller addresses the lack of attention rape has received in the social sciences, especially from scholars who pioneered the study of sexual disorders, such as Kraft-Ebing and Sigmund Freud, who wrote off rape as an act of depravity. Brownmiller argues that rape is a tactic used by all men as a form of power to keep all women in a constant state of fear, with the purpose of asserting and maintaining their dominance over women in a patriarchal society.

The theory of rape culture was further developed to describe a culture or pervasive ideology, in which male sexual violence is perceived as the norm and victims are consequently blamed for their own assaults (Brownmiller 1975, 1; Johnson and Johnson 2017, 3; Zaleski et al. 2016, 922). Drawing from social construction theory, researchers have determined that rape is perpetuated through the social construction of a rape culture (Stubbs-Richardson, Rader and 
Cosby 2018, 91). That is, societal attitudes or behaviours towards gender and sexuality that normalise sexual violence, are constructed and reproduced in society through modelling and social learning (Stubbs-Richardson et al. 2018, 91).

A rape culture perpetuates rape by socialising boys and men to be sexual aggressors, and girls and women to be sexually passive (Johnson and Johnson 2017, 3). Consequently, society has been socialised to believe that relationships involving male sexual aggression are natural and normal (Zaleski et al. 2016, 922). As a theoretical construct, rape culture has been cited frequently. However, attempts to empirically verify the construct have been limited (Johnson and Johnson 2017, 3).

The most comprehensive model of rape culture to date is the construct of rape myth acceptance first proposed by Burt in 1980 (Burt 1980, 217). According to Burt, the acceptance of traditional gender roles, adversarial sexual beliefs and acceptance of interpersonal violence are regarded as indicators of a rape culture. This model was further developed by Lonsway and Fitzgerald in 1995 to included constructs of sexism and hostility towards women (as cited in Johnson and Johnson 2017, 3).

Studies investigating rape myth acceptance have found support for the normalization of male sexual aggression (Johnson and Johnson 2017, 4). For example, one survey found that one in three men endorsed behaviourally descriptive intentions (i.e. "coerce somebody into intercourse by holding them down") to commit sexual assault, but denied these intentions when the word "rape" was used (Edwards et al. 2014, 189). These findings suggest that as a society we may have denounced the word rape, yet we have normalised the act (Johnson and Johnson $2017,4)$. This relates to the points made by Gqola $(2015,10)$ regarding societal reactions towards rape. On the one hand, we demonstrate appropriate outrage and disgust if the case of rape is related to a minor or a murder, as it represents an act of perverse and senseless violence. There is no one to blame but the perpetrator. However, in other cases, there is an amount of scepticism to behold (Hayes, Abbot and Cook 2016, 1540; Mardorossian 2014, 20). The "alleged" perpetrator is spared some of the scrutinies as male sexual aggression is normal and expected and by all accounts, the "survivor" should have known better than to put herself in that position (Hayes, Abbot and Cook 2016, 1540; Mardorossian 2014, 21). Rape culture should not be considered a subculture of feminism, but rather a systematic and collective problem in society (Zaleski et al. 2016, 924). Therefore, the cultural or societal explanation of the cause of rape needs to be moved from a micro to a macro level.

Rape is a pressing problem in South Africa as the country has been described as the rape capital of the world (Gqola 2015, 5). However, based on the rape culture framework, the pervasiveness of rape and sexual assault in society is not only a by-product of the prevalence 
of rape but also how rape is constructed by society. According to the South African Police (SAPS), 40,035 cases of rape were reported in 2017/18 (Africa Check 2018). Previously, national police commissioner, Jackie Selebi, stated that these statistics might be exaggerated due to the fact that many rape cases are reported on a Friday and Saturday night only to be withdrawn on a Monday (Smith 2004). The comment made by Selebi is speaking more to the rape culture that exists within South African society than it does to the accuracy of rape statistics. Additionally, the Institute for Security Studies cautions that the rape statistics recorded by the police does not reflect the true extent of this crime (Africa Check 2018). The withdrawal of rape accusation deserves closer examination, as it is less related to the fact that women are lying about rape, and speaks more to the failure of society to protect women and children (Smith 2004).

\section{UNIVERSITY POLICIES ON SEXUAL ASSAULT IN SOUTH AFRICA}

In South Africa, universities play a significant role in the intellectual life of society and influence the social, economic and cultural well-being of the nation. As of 2019, there are 26 public universities located across all nine South African provinces. Each of these universities belong to Universities South Africa (USAF), a membership organisation representing the South African universities which aims to promote a more "inclusive, responsive and equitable national system of higher education" (USAF 2018). Additionally, the South African Department of Higher Education and Training (DHET), functions to "provide national strategic leadership in support of the Post-School Education and Training system for improved quality of life of South Africans" (DHET 2018). Within this context, universities establish their own policies to promote the university code of conduct and ensure the safety and well-being of all students and staff. These policy documents can be based on recommendations made by USAF and the DHET, as well as the South African constitution and legislature.

Each public university has developed their own policy on sexual assault, sexual harassment or rape on campus and/or involves a student or university staff member. These policies provide definitions of sexual harassment and sexual assault, the universities' stance on such acts, and the procedures followed to respond to complaints of sexual harassment and sexual assault. A review of sexual assault/harassment policies from the top 10 universities in South Africa shows that while there are slight variations in the policies, the processes followed to handle such complaints are similar.

Comprehensive policies addressing sexual assault/harassment relating to students or staff was found for all ten universities (North-West University 2011; Rhodes University 2018; Stellenbosch University 2018; University of Cape Town 2008; University of the Free State 
2018: University of Johannesburg 2005; University of KwaZulu-Natal 2017; University of Pretoria 2016; University of the Western Cape 2014; University of Witwatersrand 2013). In these policy documents a preamble or policy statement is provided in which it is declared that the university will not tolerate rape, sexual assault or sexual harassment, sexual violence or sexual misconduct, and that the university is committed to providing an institutional environment that upholds human rights, where all can pursue their studies, careers, duties and activities free from the threat of sexual harassment. This preamble is followed by a list of definitions of terms and acronyms used throughout the document including definitions of rape and sexual assault. In four of the ten documents, consent is defined according to the Criminal Law Amendment Act 32 of 2007; two briefly mention consent; and four do not provide a definition of consent. Sexual harassment is defined in all the documents. However, three of the documents define sexual harassment according to the Protection against Sexual Harassment Act 17 of 2011 .

According to the ten policies, the university aims to provide complainants of sexual assault with all the necessary and appropriate support including informing the complainant of their rights and options; ensuring the complainant receives medical attention and counselling services; assisting in filing a report with the South African Police Service (SAPS) should the complainant decide to do so and protecting the complainant. In five of the documents, it is specifically mentioned that the university will assist with obtaining a no-contact order for the complainant if needed.

Reporting procedures for sexual harassment/assault varies between the universities as some universities have an established Equality Unit, Transformation Unit, Sexual Harassment and Safety Office or similar structures which are dedicated to dealing with such cases. All cases of sexual harassment/assault are reported to a designated reporting officer who will work with the complainant, alleged perpetrator and other university officials to address the complaint. Once a report of sexual assault/harassment has been made, the university will deal with it internally, regardless of whether the complainant decides to pursue a case with the SAPS. In the ten university policies reviewed, it is stated that either an informal process may be followed in which external parties may mediate to come to a mutually agreeable solution between the complainant and alleged perpetrator. The complainant may decide not to pursue a formal hearing. However, it is stated that the university may decide to pursue a formal hearing if it is believed that the case is serious or that the alleged perpetrator poses a risk to others. In such cases the reporting officer would make a recommendation to the Vice Chancellor of the University to proceed with the formal hearing. Four of the policies provide information regarding the penalties (suspension) should an individual be found guilty of sexual 
assault/harassment.

While the majority of these policies provide adequate information on the respective universities' stance on sexual assault/harassment, definitions of these acts and procedures followed once a complaint has been made, it is not clear how the universities are enforcing their policies, how the information is distributed to the campus community, or if these policies are effective in protecting complainants of sexual assault/harassment in the way the policy intends. For example, it is not clear how universities would proceed with an informal hearing to come to a "mutual agreement" while still ensuring that the complainant will not be re-victimised by the process. As previously mentioned, the 2016 \#Endrapeculture protests specifically pointed towards the university administrations' role in perpetuating rape culture by engaging in victimblaming practices (Wazar 2016). Five of the policies available online were approved after the 2016 protests, yet none of these refer to rape culture specifically or address any of the concerns raised by the students.

The available statistics on the number of sexual assault/harassment cases reported at South African universities may also be indicative of the effectiveness of these policies in encouraging students and staff to report incidents. Only one of the universities provide rape statistics (from 2005-2016) and revealed that in 2016 only 2 cases of rape were reported to Campus Security and/or SAPS on all the campuses (Corporate Marketing 2016). Additionally, the DHET reported that 47 cases of rape were recorded on South African university campuses in 2017. However, another university contested these statistics by saying that their Gender Equity Office (GEO) provided the DHET with an account of 29 reported cases of rape for 2017. In comparison to the previously mentioned national statistics, the number of reported rapes from South African universities appear relatively low. This further brings into question the effectiveness of the universities policies regarding rape and sexual assault.

\section{SOCIAL MEDIA AND SOCIAL MOVEMENTS}

Scholars from various disciplines including media studies, political science and gender studies, have explored how people engage in digital activism by using digital and media technologies to effect social and political change (Linder et al. 2016, 234). For example, the 2011 "Arab Spring" uprisings that occurred in Tunisia and Egypt provided researchers with the opportunity to explore how internet and social media based technologies could contribute to political change within authoritarian regimes. According to Tufekci and Wilson (2012, 363), social media platforms, in general, proved useful by providing new and alternative sources of information that the regime could not readily control, and consequently influenced citizens individual decisions about participating in the protests. 
Social media provides individuals, especially those with marginalised identities, with an option to reclaim and reinvent a collective space (Linder et al. 2016, 235; Milan 2015, 3). As social media engagement evolves, so too do the ways in which digital activism is utilised. Currently, there is a growing body of literature that focuses on the ways young people use social media to organise social movements and to keep those in power accountable through the use of hashtag activism (Keller, Mendes and Ringrose 2018, 25).

Hashtag activism is a recent development within digital activism that embodies discursive protest on social media united with a hashtagged word, phrase or sentence (Yang 2016, 14; Bogen, Bleiweiss and Orchowski 2019, 128). The \#MeToo movement, for example, gained momentum on social media platforms in October 2017 following the numerous sexual assault allegations made against American film producer, Harvey Weinstein (Peters and Besley 2018, 1). The phrase was originally used in 2006 by African American women's rights activist, Tarana Burke, on her MySpace social media page in a campaign aimed at empowering women of colour who have experienced sexual abuse. However, in 2017 the \#MeToo movement gained momentum across social media platforms when actress Alyssa Milano used it as a Twitter hashtag to respond to the Weinstein allegations and encouraged her followers to use the hashtag to raise awareness about the commonality of sexual assault, particularly in the workplace (Peters and Besley 2018, 2). The \#MeToo movement proved to be successful in capturing media and public attention as the hashtag was reportedly used 12 million times within the first 24 hours following Milano’s tweet (Keller et al. 2018, 26).

The \#MeToo movement is just one example of digital activism representing a growing trend of the public's willingness to engage with resistance and challenge oppressive structures in society through digital communication (Keller et al. 2018, 26). According to Milan (2015, 6), the hashtag-style collective narratives are useful because they are flexible, real-time and crowd controlled. It is powerful in the sense that it connects individual stories from around the world into a broader context that gives them meaning. Some scholars have critiqued digital activism by arguing that online activism does not translate to real activism; only that it allows people to demonstrate awareness of social issues without engaging in meaningful action (Linder et al. 2016). However, recent studies have shown that digital and real-time activism intersect (Eileraas 2014, 40; Pillay 2015, 155; Baer 2016, 17).

College and university campuses have long been sites of activism to promote social and political change (Linder et al. 2016, 233; Gouws 2018, 4). Indeed, in the last few years, South African higher education institutions have been characterised by various student Fallist movements (e.g. \#RhodesMustFall, FeesMustFall, PatriarchyMustFall) aimed at challenging practices and policies within the universities which have been described as being exclusionary 
and oppressive. However, by using social media and hashtag campaigns student activists were able to raise awareness and mobilise mass support across the country. The success of social media does not only lie in its ability to communicate information to a large number of people across geographical borders, but it also connects people and provides a sense of community (Milan 2015, 5; Linder et al. 2016, 233). In their study, Linder et al. (2016, 240) reported that activists found social media to be a valuable tool in providing opportunities to build a community and foster connections. As can be seen in the case of the South African \#Endrapeculture protests, the initial protest activity originated from a particular university campus. Following social media postings, other campuses initiated their own protests as students resonated with the message behind the movement. It is within this context that the \#Endrapeculture movement and the reactions to the protests are understood.

\section{METHODOLOGY}

This research study adopted a qualitative constructionist strategy of inquiry to explore the digital discourse of rape culture online. Natural observation was used to collect comments relating to the April 2016 \#Endrapeculture protests that were posted on the Facebook social media networking site. As previously mentioned, the student protests were instrumental in raising awareness of issues around rape culture on campus. The comment thread on posts relating to these protests provided insight into how people responded to the protest, and how people engaged with others to debate issues regarding the protest and the problem of rape. Therefore, these comments were subsequently analysed using content analysis to determine the presence of rape culture within this digital discourse.

\section{SAMPLING}

For the purpose of this study we searched Facebook for public posts and news stories that were related to the 2016 \#Endrapeculture protests using the hashtags; \#RUReferenceList, \#nakedprotest, \#endrapeculture and \#chapter212. The search was restricted to only include posts that were posted between the $11^{\text {th }}$ and $30^{\text {th }}$ April (the date the protests started and ended), with a comment thread of ten or more comments. Posts that generated more than ten comments were collected in order to observe how different people discuss and debate matters relating to rape culture on campus as well as their reactions to people speaking out against rape culture. According to Lijadi and Van Schalkwyk $(2015,3)$ posts with more than ten comments are appropriate to observe discussion among people online. 


\section{DATA COLLECTION}

Facebook was chosen as an appropriate data collection site for a number of reasons; Firstly, this platform has been identified as the most popular social media platform worldwide, with a reported growth of 100 million in 2008 to 2.27 billion in 2018; Secondly, Facebook has been identified as the most used social media platform in South Africa with approximately 30 per cent of the population connected as Facebook users; Lastly, comments made on the Facebook platform are considered to be part of the public domain, unless a user manages their privacy settings that only allow the individual's Facebook "friends" to see what they post, like and share. Therefore, it was not necessary to obtain consent.

Posts meeting the abovementioned criteria were copied into a word document along with the comments to be cleaned. During the data cleaning, only the comments were copied into a new document, formatted and de-identified by deleting the profile pictures, surnames and any other personal information of the commenters. Traditionally, ethical requirements call for participants to be provided with pseudonyms (Bryman 2012, 136). However, the large number of commenters under each post made this an impractical option. Instead, we de-identified the commenters by numbering them and using either $\mathrm{M}$ or $\mathrm{F}$ to designate the male or female gender respectively (ex. User 1, F). Following this, the new document was entered into Atlas.ti for analysis.

\section{DATA ANALYSIS}

Content analysis is a method of analysing written, verbal or visual communication with the goal of systematically quantifying content in terms of predetermined categories (Bryman 2012, 288; Cole 1988, 53). We used a process of deductive content analysis using an unconstrained categorization matrix to take advantage of the method's characteristic of being highly flexible when applied in digital contexts (Elo and Kyngäs 2008, 107).

The unconstrained categorisation matrix was based on the few existing studies focused specifically on rape culture and social media. This matrix was used in conjunction with other studies and literature which defined the concept of rape culture in society (Brownmiller 1975, 10; Gqola 2015, 3). The initial categories included: victim-blaming, perpetrator support, survivor support, statements about the Law and society, and the presence of patriarchy (Zaleski et al. 2016, 923; Stubbs-Richardson et al. 2018, 90; Giraldi and Monk-Turner 2017, 116; Armstrong and Mahone 2017, 2). However, using an unconstrained categorisation matrix allowed for inductive principles to filter through the analysis process, by viewing the categories in the matrix as fluid rather than fixed (Cole 1988, 55; Elo and Kyngäs 2008, 111). Therefore, while we had a predetermined set of categories by which to code the data, these were open to 
change in interpretation based on the information that emerged from the comment threads.

The data were coded using Atlas.ti software. The first round of coding involved developing conceptual codes to describe sections or chunks of the data (Bryman 2012, 298). Following this, codes were further developed and refined. The refined codes were then categorised using the matrix. Based on the emerging codes, some of the categories within the matrix were redefined to reflect the emerging themes.

\section{FINDINGS}

A total of 590 comments from eight Facebook posts were collected in August 2017. Through the content analysis, we found that reactions to the protest were mixed, with some commenters voicing support for the movement while others critiqued it. Two themes emerged from the content analysis and are discussed in this article: Rape/Rape Culture and The Role of Universities and Law Enforcement.

\section{Rape/Rape Culture}

As previously mentioned, the goal of the \#Endrapeculture protests was to highlight the universities existing policies on dealing with sexual assault on campus, which were perceived as problematic by student activists and those who have been subjected to those policies (Gouws 2018, 3). Therefore, the concerns raised by the students were directed towards the ways in which university administrations ensure the safety of their students and address sexual assault cases, rather than protesting against perpetrators of sexual assault. However, the findings from the content analysis show that some people perceived the protests as a demonstration against "rapists".

The following excerpts are public comments that were posted on Facebook in response to the \#nakedprotest which formed part of the \#Endrapeculture movement. These comments show how some people discussed and viewed the message behind the protests.

User 64 (M): “I don't get the logic for protesting topless exposing your breast. Do they believe rapists will stop raping them ... but by the look of things they may as well be inducing and enticing them."

User $62(\mathrm{M})$ : “Don't for one second think anyone that's committed/thinking about rape will see these protests and think 'Ahhh they have their breasts out, I change my mind'."

User $68(\mathrm{M})$ : "Rapist are psychopaths naked bodies are not going to stop rape."

These comments suggest that some commenters viewed the protester's message of institutional rape culture and the physical act of rape as synonymous. The commenters who believed that 
the message behind the protest was to "stop rape" described the figure of the "rapist" as someone who is not mentally stable, and who can be enticed to sexually assault someone based on their lack of clothing. This suggests that the commenter's criticism towards the \#nakedprotest lies in their interpretation of the message behind the protest. On the other hand, some commenters who voiced their support engaged in the online discussions by defending the reasoning behind the protests and attempted to explain aspects of rape culture.

User $1(\mathrm{M})$ : "Half the problem is we have over-sexualized women's bodies."

User 43 (F): "Let it be known that the violent men in black are deployed to victimize black bodies and never to stop the violence against women. The University takes more stringent measures against black protestors compared to rapists. At Stellenbosch, damage to property is more criminal than rape. Cameras are not installed in residences because they're too expensive, but men in black, who are employed at exorbitant prices, are deployed all over campus to intimidate and victimize protesting students. This is rape culture."

User $23(\mathrm{M})$ : “Blaming the victim for rape because they were 'inappropriately' dressed, 'inappropriately' exposing themselves or walking around naked is not only a form of secondary victimisation but also PERPETUATES RAPE CULTURE! Rape is in no way the victim's fault. I applaud these ladies for their protest."

These comments indicate that there was a disjuncture between commenters who challenged rape culture and those who problematized rape. In their stance against rape culture, the protesters and the commenters supporting the protest engaged in a narrative which implicates the university management and other societal and institutional cultures as tools of patriarchy by pointing out how practices of victim-blaming, perpetrator support and sexualisation perpetuate a rape culture. However, other commenters pointed out that protesting topless would not stop the rapist. In this, they shift the blame (accountability) from the university management and other societal structures towards the rapist.

In the comment sections, rapists were described as mentally disturbed, aggressive and driven by the need to dominate. The failure to make connections between dominating male aggressive behaviour and a rape culture framework is problematic (Brownmiller 1975, 10). Firstly, by problematizing the rapist, people may be excused from critical reflection into how their own behaviours may contribute to the perpetuation of a rape culture. Secondly, the resistance commenters showed the concept of rape culture hinders effective communication and engagement, as people believe they are engaging on the same topic, even though they are not. 


\section{The role of universities and law enforcement}

The \#Endrapeculture protests represented the culmination of students' frustrations with and anger towards the perceived role that university management played in perpetuating rape culture on campus - through their actions that victimised those who report sexual assault and treating the perpetrators with leniency. In the comments section, respondents reiterated these critiques. Some of the commenters pointed out disparities in how the university deals out punishment to their students, claiming that the university takes more action to protect the institution, rather than protecting the students.

User 43 (F): "damage to property is more criminal than rape. Cameras are not installed in residences because they're too expensive, but men in black, who are employed at exorbitant prices, are deployed all over campus to intimidate and victimize protesting students. This is rape culture."

User 54 (F): "good for them [Protesters], its time these universities start protecting ALL students not just the males."

User 55 (F): "as South African student it's deeply unsettling knowing the campus is and was never safe."

User $27(\mathrm{~F})$ : "There is the harassment office, counselling centre, and camps protection unit. Now what these students are protesting about is that when they use these means to report a crime they are disrespected and not treated fairly, thus resulting in their cases never being heard or never making it to the police station."

User 57 (F): "They protect these boys on campus due to reputation it's sick. Same as the military."

User $58(\mathrm{M})$ : “When are these damn colleges going to make it crystal clear that this behaviour is not going to be tolerated! Damn!"

These comments indicate perceptions that university management is more concerned with protecting its reputation - and by extension, the male students (as perpetrators) - rather than protecting all of the students. Despite services such as student counselling, being made available, even these support services have been critiqued by students for perpetuating rape culture. This indicates that students feel a lack of trust towards the university as an institution.

While some of the commenters pointed out the problematic nature of the university structures, others felt that the role of the university management should be minimal in handling reports of sexual assault and that law enforcement should deal with all cases of reported sexual assault.

User 59 (M): “Isn't the right way to do it to go open a case by SAPS and let them handle it???" User 60 (F): "I agree but it is a case for the police."

User $61(\mathrm{M})$ : "how about they go to the police and stop this nonsense." 
These comments suggest that some believe the students should have protested at the police stations. The problem of rape is thus perceived by some members of the public as a situation that should only be handled by law enforcement. However, previous studies have shown that rape culture is entrenched in all manner of institutions, and survivors of sexual assault are often victimised by law enforcement and the courts (Carroll et al. 2016, 2; Wakelin and Long 2003, 478; Salter 2013, 3). Additionally, comments like this indicate that there is a lack of understanding concerning the procedures that need to be followed when sexual assault is reported on campus. In South Africa, universities rely on their own policies and self-regulation to process sexual assault complaints (Lebitse 2019, 5).

\section{DISCUSSION}

The findings from the study suggest that the reactions to the protest were mixed, with some commenters voicing their support for the protesters, while others criticised the movement. The critique against the protesters may also be understood in relation to the public reaction towards the previous protests, as some members of the public believed the students were protesting for trivial reasons (Gouws 2018, 9).

In this study, it was demonstrated that those who supported the \#Endrapeculture protests were more likely to believe that the university should be held accountable for the role it plays in perpetuating rape culture, while those who criticised the protesters believed that sexual assault cases should be dealt with by law enforcement. This raises questions concerning the role the university can and should take on when dealing with sexual assault cases. Is it enough for university authorities to critically re-evaluate their existing policies on sexual assault and the resources available to students who report these assaults? While the message behind the \#Endrapeculture protests was aimed at highlighting the perpetuation of a rape culture within the institution, the protests also raised awareness about rape culture within South African society (Gouws 2018, 9). Within this context, law enforcement institutions have also been accused of perpetuating rape culture. According to Swemmer $(2019,4)$, legal systems in South Africa rely on the use of gender stereotypes and rape myths when prosecuting cases of sexual assault. Previous studies have shown that the use of these gender stereotypes and rape myths results in acts of victim-blaming (Swemmer 2019, 4; Mardorossian 2014, 7; Morales 2015, 18). The secondary victimisation experienced by rape survivors at the hand of the courts and law enforcement has been described as a traumatic experience by those who have been through the process (Swemmer 2019, 4). Therefore, not only is it necessary to address rape culture within the institutional culture of the university but also within society. As previously mentioned, both 
USAF and the DHET recognise the influence South African universities in society and aim to ensure that these universities are able to significantly contribute to the socio-economic and cultural development of the nation (DHET 2018; USAF 2017).

Digital activism has been critiqued by scholars for creating a false perception of increased political engagement that doesn't translate into actual change (Linder et al. 2016, 235; Keller et al. 2018, 33). While the purpose of this study was not to determine whether the protests succeeded in bringing about social change, it should be noted that following the \#Endrapeculture protests, a South African university revealed that they would launch a Task Force to investigate the climate of rape culture on campus. The Task Team released their report the year following the protest which included several recommendations to address rape culture. While we are not able to draw conclusions concerning whether or if any of these recommendations will result in significant changes on campus, we do argue that the use of social media hashtag campaigns during the \#Endrapeculture protests played an instrumental role in generating mass support and media coverage of the protests, thereby placing pressure on university authorities to respond.

Evidence suggests that social media can and should be used as a platform to address various social issues such as gender inequality, rape culture and racism (Stubbs-Richardson et al. 2018, 107; Giraldi and Monk-Turner 2017, 120). University and college administrations should consider utilising social media platforms to engage with students and address problems of rape culture and sexual assault on campus. However, we argue that more empirical evidence is needed to better understand how to positively disseminate relevant information on social media in a way that leads to social change.

\section{CONCLUSION}

In this article, we explored the public reaction to the 2016 \#Endrapeculture protests through content analysis of Facebook comments relating to the protests. The findings show that people could engage with each other in a debate on the Facebook comment threads regarding the topic of rape culture. However, these debates did not reflect effective communication between commenters or critical engagement with the topic.

The findings from this study raised questions regarding the roles university and college administrations should take on regarding sexual assault on campus. Those who supported the protest argued that the university should critically evaluate their policies and address the rape culture on campus, while others believed the law enforcement should deal with sexual assault cases exclusively. However, societal institutions, including law enforcement have also been critiqued for perpetuating rape culture, thereby indicating that rape culture is a societal problem 
and not limited to campuses. More research is needed to examine the current university policies on sexual assault to determine the role universities can and should play in handling sexual assault cases on campus.

Both the local 2016 \#Endrapeculture protests as well as the global hashtag campaigns aimed at creating awareness about sexual assault in society indicate that there is a need to address rape culture in society. Based on the findings from our study, we argue that the first step to addressing rape culture is to formalise rape culture education. Universities and other institutions can use social media platforms as a method of raising awareness and disseminating information about rape culture education. However, more research should be done to understand the mechanisms behind effective social media engagement.

\section{REFERENCES}

Africa Check. 2018. Factsheet: South Africa's crime statistics for 2017/18. Africa Check. https://africacheck.org/factsheets/factsheet-south-africas-crime-statistics-for-2017-18/ (Accessed 30 September 2018).

Armstrong, Cory L. and Jessica Mahone. 2017. "It's on us." The role of social media and rape culture in individual willingness to mobilize against sexual assault. Mass Communication and Society 20(1): 92-115. https://doi.org/10.1080/15205436.2016.1185127

Baer, Hester. 2016. Redoing feminism: Digital activism, body politics, and neoliberalism. Feminist Media Studies 16(1): 17-34. https://doi.org/10.1080/14680777.2015.1093070

Bogen, Katherine W., Kaitlyn Bleiweiss and Lindsay M. Orchowski. 2019. Sexual violence Is \#NotOkay: Social reactions to disclosures of sexual victimization on twitter. Psychology of Violence 9(1): 127-37. http://dx.doi.org/10.1037/vio0000192

Brownmiller, Susan. 1975. Against our will: Men, women and rape. New York: Ballentine Books.

Bryman, Alan. 2012. Social research methods. $4^{\text {th }}$ Edition. Oxford: Oxford University Press.

Burt, M. 1980. Cultural myths and support for rape. Journal of Personality and Social Psychology 2: 217-230. http://doi.org/10.1037/0022-3514.38.2.217

Carroll, Marjorie H., Judith Rosenstein, John D. Foubert, M. Diane Clark and Lisa Korenman. 2016. Rape myth acceptance: A comparison of military service academy and civilian fraternity and sorority students. Milatary Psychology 28(5): 1-12. https://doi.org/10.1037/mil0000113

Cole, F. L. 1988. Content analysis: Process and application. Clinical Nurse Specialist 2(1): 53-57. https://doi.org/10.1097/00002800-198800210-00025

Corporate marketing. 2016. "What is rape culture?" and other questions. Stellenbosch University. https://www.sun.ac.za/english/Lists/news/DispForm.aspx?ID=3811 (Accessed 30 August 2019).

Dematteo, David, Meghann Galloway, Shelby Arnold and Unnati Patel. 2015. Sexual assault on college campuses: A 50-state survey of criminal sexual assault statutes and their relevance to campus sexual assault. Military Psychology 21(3): 227-38. http://dx.doi.org/10.1037/law0000055

Department of Higher Education and Training. 2018. Annual report 2017/18. http://www.dhet.gov.za/ Commissions\%20Reports/DHET\%20Annual\%20Report\%20\%202017_18\%20.pdf (Accessed 30 August 2019).

DHET see Department of Higher Education and Training.

Edwards, Sarah R., Kathryn A. Bradshaw and Verlin B. Hinsz. 2014. Denying rape but endorsing forceful intercourse: Exploring differences among responders. Violence and Gender 1(4): 188193. https://doi.org/10.1089/vio.2014.0022 
Eileraas, Karina. 2014. Sex(t)Ing revolution, femen-izing the public square: Aliaa Magda Elmahdy, nude protest and transnational feminist body politics. Signs 40(1): 40-52. https://doi.org/ $10.1086 / 677073$

Elo, Satu and Helvi Kyngäs. 2008. The qualitative content analysis process. Journal of Advanced Nursing 62(1): 107-15. https://doi.org/10.1111/j.1365-2648.2007.04569.x

Fedina, Lisa, Jennifer Lynne Holmes and Bethany L. Backes. 2018. Campus sexual assault: A systematic review of prevalence research from 2000 to 2015. Trauma, Violence and Abuse 19(1): 76-93. https://doi.org/10.1177/1524838016631129

Giraldi, Ashley and Elizabeth Monk-Turner. 2017. Perception of rape culture on a college campus: A look at social media posts. Women's Studies International Forum 62: 116-24. https://doi.org/ 10.1016/j.wsif.2017.05.001

Gouws, Amanda, 2018. \#EndRapeCulture campaign in South Africa: Resisting sexual violence through protest and the politics of experience. Politikon 45(1): 3-15. https://doi.org/10.1080/ 02589346.2018.1418201

Gqola, Pumla. 2015. Rape: A South African nightmare. Johannesburg: MFBooks Johannesburg.

Hayes, Rebecca M., Rebecca L. Abbott and Savannah Cook. 2016. It's her fault: Student acceptance of rape myths on two college campuses. Violence Against women 22(13): 1540-1555. https://doi.org/ $10.1177 / 1077801216630147$

Johnson, Nicole L. and Dawn M. Johnson. 2017. An empirical exploration into the measurement of rape culture. Journal of Interpersonal Violence 00(0): 1-26. https://doi.org/10.1177/ 0886260517732347

Keller, Jessalynn, Kaitlynn Mendes and Jessica Ringrose. 2018. Speaking “unspeakable things": Documenting digital feminist responses to rape culture. Journal of Gender Studies 27(1): 22-36. https://doi.org/10.1080/09589236.2016.1211511

Lebitse, Palesa. 2019. Sexual violation: Education institutions need a law of their own. https://mg.co.za/article/2018-09-07-00-sexual-violation-education-institutions-need-a-law-oftheir-own

Lijadi, Anastasia and Gertina J. van Schalkwyk. 2015. Online Facebook focus group research of hardto-reach participants. International Journal of Qualitative Methods 14(5): 1-9. https://doi.org/10.1177/1609406915621383

Linder, Chris, Jess S. Myers, Colleen Riggle and Marvette Lacy. 2016. From margins to mainstream: Social media as a tool for campus sexual violence activism. Journal of Diversity in Higher Education 9(3): 231-244.

Mardorossian, Carine M. 2014. Framing the rape victim: Gender and agency reconsidered. New Brunswick: Rutgers University Press.

Milan, Stefania. 2015. When algorithms shape collective action: Social media and the dynamics of cloud protesting. Social Media and Society 1(2). https://doi.org/10.1177/2056305115622481

Morales, Sayda Valentina. 2015. Bringing blurred lines into focus: The relationship between rape culture and gendered subcultures at whitman college. Honour's thesis, Whitman College, 1-81.

North-West University. 2011. Behavioural manual. North-West University. http://base2-nwu-ac-za. web.nwu.ac.za/sites/intranet.nwu.ac.za/files/files/3Pr-3.13M_e_.pdf(Accessed 22 August 2019.).

Peters, Michael A. and Tina Besley. 2018. Weinstein, sexual predation, and "rape culture": Public pedagogies and hashtag internet activism. Educational Philosophy and Theory 1857: 1-7. https://doi.org/10.1080/00131857.2018.1427850

Phipps, Alison, Jessica Ringrose, Emma Renold and Carolyn Jackson. 2018. Rape culture, lad culture and everyday sexism: Researching, conceptualizing and politicizing new mediations of gender and sexual violence. Journal of Gender Studies 27(1): 1-8. https://doi.org/10.1080/ 09589236.2016.1266792

Pillay, Suntosh R. 2015. Silence is violence: (Critical) psychology in an era of Rhodes Must Fall and 
Fees Must Fall. South African Journal of Psychology 46(2): 155-59. https://doi.org/10. $1177 / 0081246316636766$

Rentschler, Carrie A. 2014. Rape culture and the feminist politics of social media. Girlhood Studies 7(1): 65-82. doi: 10.3167/ghs.2014.070106.

Rentschler, Carrie. 2015. \#Safetytipsforladies: Feminist twitter takedowns of victim blaming. Feminist Media Studies 15(2): 353-56. https://doi.org/10.1080/14680777.2015.1008749

Rhodes University. 2018. Sexual offence policy for students. Rhodes University. https://www.ru.ac.za/media/rhodesuniversity/content/institutionalplanning/documents/Sexual_ Offences_Policy_for_students.pdf (Accessed 22 August 2019).

Salter, Michael. 2013. Justice and revenge in online counter-publics: Emerging responses to sexual violence in the age of social media. Crime, Media, Culture 9(3): 1-18. https://doi.org/ $10.1177 / 1741659013493918$

Smith, C. 2004. Rape has become a way of life in South Africa. IOL News. www.hst.org.za/news/rapehas-become-way-life-south-africa (Accessed 23 March 2017).

Stellenbosch University. 2018. Unfair discrimination and harassment. Stellenbosch University. http://sunrecords.sun.ac.za/controlled/C4\%20Policies\%20and\%20Regulations/FINAL\%20Polic y\%20on\%20Unfair\%20Discrimination\%20and\%20Harassment\%20ENG\%202016.pdf (Accessed 22 August, 2019).

Stubbs-Richardson, Megan, Nicole E. Rader and Arthur G. Cosby. 2018. Tweeting rape culture: Examining portrayals of victim blaming in discussions of sexual assault cases on twitter. Feminism and Psychology 28(1): 90-108. https://doi.org/10.1177/0959353517715874

Swemmer, Sheena. 2019. Ethical loneliness and the development of a victim-focused approach to rape cases in South Africa Aggression and Violent Behavior. https://doi.org/10.1016/ j.avb.2019.01.014

Tufekci, Zeynep and Christopher Wilson. 2012. Social media and the decision to participate in political protest: Observations from Tahrir Square. Journal of Communication 62(2): 363-79. https://doi.org/10.1111/j.1460-2466.2012.01629.x

Universities South Africa. 2017. Strategic framework. Universities South Africa. https://www.usaf.ac.za/\# (Accessed 30 August 2019).

University of Cape Town. 2008. Sexual offences policy. University of Cape Town. http://www.uct.ac.za/sites/default/files/image tool/images/328/about/policies/Policy_Sexual_Ha rassment_2008.pdf (Accessed 22 August 2019).

University of Johannesburg. 2005. Sexual harassment policy. University of Johannesburg. https://www.uj.ac.za/about/Documents/policies/Sexual\%20Harassment\%20Policy.pdf (Accessed 22 August 2019).

University of KwaZulu-Natal. 2017. Sexual harassment policy. University of KwaZulu-Natal. https://aessupport.ukzn.ac.za/wp-content/uploads/2018/07/Sexual-harassment-policy.pdf (Accessed 22 August 2019).

University of Pretoria. 2016. Code of conduct on the handling of sexual harassment. University of Pretoria. https://www.up.ac.za/media/shared/409/code-of-conduct-on-the-handling-of-sexualharrasment.zp85249.pdf (Accessed 22 August 2019).

University of the Free State. 2018. Sexual harassment, sexual misconduct and sexual violence policy. University of the Free State. https://www.ufs.ac.za/docs/default-source/all-documents/sexualharassment-sexual-misconduct-sexual-violence-policy_council-approved_15-06-2018-(1).pdf? sfvrsn=dc3dbe21_0 (Accessed 22 August 2019).

University of the Western Cape. 2014. Sexual harassment policy. University of the Western Cape. https://www.uwc.ac.za/SO/HR/Pages/policies.aspx (Accessed 22 August 2019).

University of Witwatersrand. 2013. Sexual harassment, sexual assault and rape policy and procedures. University of Witwatersrand. https://www.wits.ac.za/media/wits-university/students/genderequity-and-tolerance/documents/HRG.10\%207\%20Apr\%202014\%20Wits\%20Sexual $\% 20$ 
Harassment\%20Policy.pdf (Accessed 22 August 2019).

USAF see Universities South Africa.

Wakelin, Anna and Karen M. Long. 2003. Effects of victim gender and sexuality on attributions of blame to rape victims. Sex Roles 49(9-10): 477-87. https://doi.org/10.1023/A:1025876522024

Wazar, Mishka. 2016. Chapter 2.12: The Campaign against Rape Culture. https://www.ru.ac.za/ studentlife/latestnews/chapter212thecampaignagainstrapeculture.html

Yang, Guobin. 2016. Narrative agency in hashtag activism: The case of \#BlackLivesMatter. Media and Communications 4: 13-17. https://doi.org/10.17645/mac.v4i4.692

Zaleski, Kristen L., Kristin K. Gundersen, Jessica Baes, Ely Estupinian and Alyssa Vergara. 2016. Exploring rape culture in social media forums. Computers in Human Behavior 63: 922-27. https://doi.org/10.1016/j.chb.2016.06.036 